\title{
Implementation of Inquiry Learning Model to Improve Pencak silat Learning Outcomes
}

\author{
Norma Anggara, Perdinanto \\ Department of Sport Education and Health \\ Universitas Lambung Mangkurat, Banjarbaru, Indonesia \\ norma.anggara@ulm.ac.id
}

\begin{abstract}
The purpose of using inquiry strategies in learning is to develop the ability to think systematically, logically, and critically, or develop intellectual abilities as part of mental processes. Thus, in inquiry students are not only required to master the subject matter but also how they can use their potential. This research uses the action research method using a research design model Kemmis and Mc. Taggart in the form of cycles or rounds of activities that include the stages of 1) planning, 2) action, 3) observation and 4) reflection at each round. The subjects of this study were students' class of A1 class 52 people and class A2 54 people totally 106 students. The result of this research is before being given an inquiry method, the results of absorption of learning from the whole inquiry learning method. There will be a significant change by conducting action research conducted for 16 meetings with a duration of 2 cycles. Based on the results of the final test percentage on the value of the middle test cycle 1 average is $22.64 \%$. The value of cycle 2 is $79.25 \%$. There was a significant change. Thus, an increase in the learning outcomes is the basics of self-defense to students.
\end{abstract}

Keywords: implementation, inquiry method, Pencak silat

\section{INTRODUCTION}

Pencak silat was derived from the cultural elements of the Indonesian people, which is strongly believed by the warriors and martial arts experts that the Malay people really used this martial art since prehistoric times [1]. "This Pencak silat is a sport that results from Indonesian human culture to defend/maintain its existence and integrity towards the environment/natural surroundings to achieve harmony in life in order to increase faith and piety in God Almighty" [2]. Pencak silat has begun to spread to almost all countries in the world and can be seen in competitions at the regional, tertiary, regional and international levels, so the competition to reach the top achievements is very tight. This situation provides inspiration for experts and Pencak silat trainers to find and formulate effective training and learning concepts to improve athlete achievement.

Pencak silat is a branch of martial arts that requires proficiency in mastering basic techniques. The basic techniques that must be mastered are the techniques of kicks, punches, avoidance, and defiance. To achieve optimal performance, these basic techniques must be carried out with strong, fast, precise and coordinated movements [1]. One of the oldest State Universities in South Kalimantan that is
Lambung Mangkurat University has several Faculties, including the Teacher Training and Education Faculty which is the only Teacher Training Faculty having Physical Education Study Program. Physical Education Study Program is one of the organizers of martial arts subjects held in the even semester every year. On the learning, the duty or obligation of an educator/lecturer certainly wants success in learning to be achieved properly. The success of the learning process is inseparable from the ability of lecturers to develop learning models oriented to increase the intensity of effective student involvement in the learning process.

The development of an appropriate learning model basically aims to create learning conditions that enable students to learn actively and fun so that students can achieve optimal learning and achievement. To be able to develop effective learning models, presumably, the lecturer must have adequate knowledge regarding the concepts and ways of implementing these learning models in the learning process. An effective learning model has a relationship with the level of understanding of lecturers on the development and conditions of the intellectual abilities of students who are different when in the field. Teaching methods commonly used by lecturers in learning models in other subjects include the method of discussion and assignments and others. This activity is carried out when face to face or during scheduled lecture activities. Thus, in this case the researcher wants to try to explore a little about the application of the inquiry approach to the communication model used, not one-way communication or communication as action, but multidirectional communication or communication as an action role. The inquiry model in learning can be more used to students to prove something about the subject matter they have learned. Thus, researchers are interested in wanting to study and explore in depth the learning model that is intended to be used when delivering lectures, namely the implementation of inquiry learning on mastery of the martial arts basics of martial arts students of Physical Education study programs, Department of Sports and Health Education, Faculty of Teacher Training and University Education Gastric Mangkurat 2016 school year 2017/2018.

\section{A. Action Research Concepts}

Research is basically an activity or a systematic process to solve problems carried out in the application of scientific methods. 
that are intertwined in such a way that it appears to create a beautiful harmony of movement.

\section{Learning Inquiry Model}

The term inquiry comes from English, which is inquiry which means a question or inquiry. Inquiry learning is a series of learning activities that maximally involve all students' abilities to search and investigate systematically, critically, logically, analytically, so that students can formulate their own findings with confidence. This learning model was developed by a character named Suchman. Suchman believes that children are curious individuals of all things. The theory underlying this learning model.

\section{The Principle of Using Inquiry Learning Models}

Inquiry learning emphasizes student activities maximally to search and find, meaning that this learning places students as subjects of learning. In the learning process, students not only act as recipients of the lesson through verbal explanation of the teacher, but they play a role in finding the core of the subject matter itself.

All activities undertaken by students are directed to seek and find their own answers to something that is questioned, so that it is expected to foster an attitude of confidence (selfbelief). Learning activities are usually carried out through a question and answer process between teacher and students. Therefore, the teacher's ability to use questioning techniques is a major requirement in conducting inquiry.

The purpose of using inquiry strategies in learning is to develop the ability to think systematically, logically, and critically, or develop intellectual abilities as part of mental processes. Thus, in inquiry students are not only required to master the subject matter, but how they can use their potential [4].

\section{E. Concepts of Physical Education}

Definition of physical education experts is a very broad field of study. The point of concern is the increase in human motion. critical thinking skills, emotional stability, and others [5]. More specifically, physical education is related to human relations and the area of education. Physical education is a medium to encourage the development of motor skills, physical abilities, and knowledge. With physical education students will obtain various expressions that are closely related to pleasant personal messages. Jesse Feiring Williams, Physical education is several selected human physical activities that are carried out to get the desired results [6].

\section{METHOD}

This research uses the action research method, by using the research design model Kemmis and Mc. Taggart in the form of cycles or rounds of activities that include stages 1) planning (planning), 2) action (action), 3) observation (observing) 4) reflection (reflecting), at each round [7]. The subjects of this study were students' class of A1 class 52 people and class A2 54 people all sample these 106 students. 
Psychomotor results obtained from the total score of students in doing the test of the elements of motion which are assessed from the truth in doing each of the basic movements of martial arts on Pencak silat. Indicators assessed include: (1) martial arts attitudes, (2) implementation of horse-horse attitude, (3) combination movements.

The test is carried out by giving the basics of martial arts tests to Pencak silat of an improvement in the learning process after being given an action by applying learning models of martial arts basics on Pencak silat with the inquiry approach pattern.

\section{RESULTS AND DISCUSSION}

Before carrying out the action research process, researchers first conduct an evaluation or reflection on the implementation of learning the basics of self-defense, which have been carried out at previous meetings or during the initial test by evaluating the results of the midterm exam. Physical education study program students, who took part in learning the basics of self-defense which consisted of two classes, namely A1 and A2 2016, amounting to 106 students. Judging from the learning process at the beginning of the meeting, it can be said that it has not been able to master the overall skills.

After the evaluator made an assessment at the ninth meeting by taking the midterm exam score, the results obtained were not possible. Students are still not able to make good and right movements, but what must be considered is that the movements must be refined to make it easier to move the position of the horses. From the results of the final test in cycle I will answer whether by giving an inquiry learning model students can successfully master the basic movements of martial arts in the even semester of 2017/2018 Physical Education study programs. It turns out that based on the assessment analysis, there were many significant improvements, which were shown from several students who were able to master the movements with good, subtle, and directed components. Here the evaluator no longer needs to continue the next cycle, because with only one cycle the achievement of learning outcomes has reached $80 \%$ of the total number of students already able to master the material. From the final test results on the first cycle or the final exam value to the next, there will be a significant change. The results of learning the basics of student self- defense Physical education study programs, can be seen from the results of calculations from the final test data or final exam results as follows. From the final test results on the first cycle or the final exam value to the next, there will be a significant change. The results of learning the basics of student self-defense Physical education study programs, can be seen from the results of calculations from the final test data or final exam results in program study Physical Education JPOK FKIP ULM.

TABLE I. RESUlt of Mid TeSt AND FinAl TeSt.

\begin{tabular}{|l|l|l|c|c|c|c|}
\hline \multirow{2}{*}{ No } & \multirow{2}{*}{ Category } & \multirow{2}{*}{$\begin{array}{c}\text { Standard } \\
\text { Value }\end{array}$} & \multicolumn{2}{|c|}{ Mid test } & \multicolumn{2}{c|}{ Final Test } \\
\cline { 4 - 7 } & & & $\boldsymbol{F}$ & $\boldsymbol{\%}$ & $\boldsymbol{F}$ & \% \\
\hline 1. & Passing & $>60$ & 24 & 22.64 & 84 & 79.25 \\
\hline 2. & $\begin{array}{l}\text { Not } \\
\text { Passing }\end{array}$ & $<60$ & 82 & 77.36 & 22 & 20.75 \\
\hline$\sum$ & & 106 & 100 & 106 & 100 \\
\hline
\end{tabular}

\section{CONCLUSION}

This inquiry learning method, there will be a significant change by conducting an action research conducted for 16 meetings with a duration of 2 cycles. Based on the results of the final test percentage on the value of midterm exam cycle I to final exam value of cycle II, there was a significant change. Thus an increase in the learning outcomes of the basics of self-defense in students of the physical education study program Department of Sport and Health Education, Faculty of Teacher Training and Education, Lambung Mangkurat University, Banjarbaru.

\section{REFERENCES}

[1] L. Johansyah Pencak silat edisi ke tiga. Jakarta: Raja Grafindo Persada: 2016.

[2] I. Iskandar,.Pisikologi Pendidikan Sebuah Orientasi Baru. Jakarta: Refrensi, 2012

[3] Peraturan PB IPSI. Hasil Musyawarah Nasional. Jakarta: 2012.

[4] H. Jumata, Model dan Metode Pembelajaran. Jakarta: Ghalia Indonesia, 2014.

[5] J.S. Husdarta, Manajemen Pendidikan Jasmani. Bandung: Alfabeta, 2012.

[6] E. R. Trisna, Strategi Pembelajaran Pendidikan jasmani. Bandung: Alfabeta, 2013.

[7] G. E. Mills,. Action research: A guide for the teacher researcher Prentice-Hall, Inc., One Lake Street, Upper Saddle River, New Jersey 07458, 2000 . 